African Crop Science Journal by African Crop Science Society is licensed under a Creative Commons Attribution 3.0 Uganda License. Based on a work at www.ajol.info/ and www.bioline.org.br/cs

DOI: https://dx.doi.org/10.4314/acsj.v28i1.18S

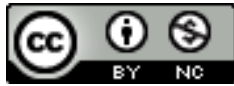

\title{
UTILISATION OF LABOUR AMONG PIG FARMERS IN NORTHERN UGANDA
}

\section{J. MUGONYA, S.W. KALULE and E.K. NDYOMUGYENYI}

Department of Rural Development and Agribusiness, Gulu University, P. O. Box 166, Gulu, Uganda ${ }^{1}$ Department of Animal Production and Range Management, Gulu University, P. O. Box 166,

Gulu, Uganda

Corresponding author: mugonyajohn@gmail.com

\begin{abstract}
In many sub-Saharan countries, pig (Susscrofa domesticus) production is increasingly an important food security and income generating activity for smallholder farmers. This is attributed to the high prospects for vigilance of the pork market, driven by urbanisation, population growth and dietary transition towards more animal protein per capita. Therefore, increasing pig production is one of the viable pathways to get smallholder farmers out of poverty and food insecurity. Although there are extensive studies about the elements of pig production, such as feeding, breeding and space requirements; little work has been done on distribution of innovation behaviour and the socio-economic factors that influence labour utilisation in the region. The objective of this study was to determine the socio-economic factors that influence labour (family or hired) utilisation and distribution of innovation behaviour among pig farmers in Northern Uganda. Through a cross sectional survey and descriptive analysis, we characterised smallholder pig farmers in the northern Uganda by type of labour used for pig production, and explored the distribution of the dimensions of innovation behaviour (exploration, experimentation, adaptation and modification) among them. Results revealed that young educated farmers with non-farm employment, a smaller household size, belonging to a farmer group and who had many pigs were more likely to use hired labour than those with counter characteristics. There were significant differences in the number of farmers who exhibited the different dimensions of innovation behavior. Therefore, interventions to boost pig production through the use of hired labour should consider the socio-economic differences among farmers which determine labour constraints they face.
\end{abstract}

Key Words: Innovation behaviour, labour utilisation, pig production

\section{RÉSUMÉ}

Dans de nombreux pays sub-sahariens, la production porcine (Susscrofa domesticus) est de plus en plus une activité alimentaire et génératrice de revenus importante pour les petits exploitants. Cela est attribué aux fortes perspectives de vigilance du marché du porc, tirées par l'urbanisation, la croissance démographique et la transition alimentaire vers davantage de protéines animales par habitant. Par conséquent, l'augmentation de la production porcine est l'une des voies viables pour les petits 
exploitants de sortir de la pauvreté et de l'insécurité alimentaire. Bien qu'il existe des études approfondies sur les éléments de la production porcine, tels que l'alimentation, l'élevage et les besoins d'espace; peu de travaux ont été effectués sur la répartition des comportements d'innovation et les facteurs socio-économiques qui influencent l'utilisation de la main-d'œuvre dans la région. L'objectif de cette étude était de déterminer les facteurs socio-économiques qui influencent l'utilisation de la maind'œuvre (familiale ou salariée) et la répartition des comportements d'innovation parmi les éleveurs de porcs du nord de l'Ouganda. À travers une enquête transversale et une analyse descriptive, nous avons caractérisé les petits éleveurs de porcs dans le nord de l'Ouganda par type de travail utilisé pour la production porcine, et exploré la distribution des dimensions du comportement d'innovation (exploration, expérimentation, adaptation et modification) entre eux. Les résultats ont révélé que les jeunes agriculteurs instruits ayant un emploi non agricole, une espace de ménage plus petite, appartenant à un groupe d'agriculteurs et qui avaient de nombreux porcs étaient plus susceptibles d'avoir recours à la main-d'œuvre salariée que ceux ayant des caractéristiques contraires. Il y avait des différences significatives dans le nombre d'agriculteurs qui présentaient les différentes dimensions du comportement d'innovation. Par conséquent, les interventions visant à stimuler la production porcine par le recours à la main-d'œuvre salariée devraient tenir compte des différences socioéconomiques entre les agriculteurs qui déterminent les contraintes de travail auxquelles ils sont confrontés.

Mots Clés: Comportement d'innovation, utilisation de la main-d'œuvre, production porcine

\section{INTRODUCTION}

Pigs (Susscrofa domesticus) are a major component of livestock production world wide. In Sub-Saharan Africa (SSA), production of pork has more than tripled since 2000; with Uganda producing $12 \%$ of the region's pig meat, from about three million pigs annually (HarvestChoice, 2015). The greatest concentration of pig rearing households is highest in the central region (56\%), followed by western $(30.1 \%)$, eastern $(28.8 \%)$ and lastly northern region at $14.2 \%$ (Tatwangire, 2014; Ndyomugyenyi and Kyasimire, 2015)

The growth in the level of pig production increases the competition for key production resources with other agricultural sub-sectors. Therefore, pig farmers have to constantly make choices regarding how much capital, land and labour to allocate to each enterprise to achieve the overall household objective of sufficient income and food security. Besides land, labour is the most important production factor for pig farming households, which imposes production and management constraints when in limited supply (Bedemo et al., 2013). Therefore, understanding farmers' labour allocation decisions to the pigs sub-sector is important so as to devise strategies to increase production of pork and other pig products. These interventions further call for a critical enabler called innovation behaviour, which allows farmers to enhance production through optimised combinations of production resources for maximum gain.

Innovation behaviour has been defined as the extent to which farmers explore, test or alter a new idea or technology or improve an existing practice subject to social, economic, technological and environmental constraints (Schiederig et al., 2011; Liao, 2017). It has four dimensions, including (i) exploration of new practices which refers to the search for innovations/technology and flexibility with new alternatives; (ii) experimentation of new practices which is the propensity to test new technology and observe subtle changes; (iii) adaptation of new practices which is the process of familiarising new tools, practices and technologies to suit local conditions, resource endowments and preferences of individuals and communities; and (iv) modification of existing practices which is improvement of existing practices (Popadiuk 
and Vidal, 2009; Tambo and Wünscher, 2014; Bragdon and Smith, 2015).

Farmer innovation is reportedly a game changer in the efforts of commercialising smallholder pig production (Èandek-Potokar et al., 2017). Moreover, innovation can reduce labour demand through use of labour saving pig production technologies, such as indigenous micro-organisms (IMO) technology, which reduces the labour required to handle and dispose pig waste. To innovate, farmers need to explore new pig rearing practices, experiment and adapt them and/or modify existing practices.

However, a knowledge gap exists to what extent pig farmers explore, experiment, adapt new pig rearing practices or modify existing practices. Although, it is known that many smallholder farmers use mostly family labour for pig production (Ciaian et al., 2012); there is a paucity of literature on socio-economic factors which predispose them to use either family or hired labour. Therefore, the objective of this study was to determine the socioeconomic factors that influence different types of labour (family or hired) utilisation and the distribution of the dimensions innovation behaviour among pig farmers in Northern Uganda.

\section{METHODOLOGY}

Study area. This study was conducted in the districts of Gulu and Omoro in northern Uganda, between October and November 2018. The districts lie between longitude $2.7152^{\circ}-2.8186^{\circ} \mathrm{N}$ and latitude $32.4467^{\circ}$ $32.4920^{\circ} \mathrm{E}$, and range between 600 and 1,200 $\mathrm{m}$ above the sea. Pig production in the region is largely smallholder-based, with majority of the households keeping only 6 to 20 pigs. About $64 \%$ of the households keep local pig breeds, managed mainly through tethering, with $60 \%$ of the labour provided by women (Ikwap et al., 2014). Within Gulu, the study was conducted in Paicho Sub-County located in Aswa County; while in Omoro district, the study was done in Koro Sub-County situated in Torchi County.

Research design and sampling. The study employed a cross sectional design, where data were collected from smallholder producers of pigs. The design was chosen because it is a one-time research approach, and thus, it is cost effective in terms of time and financial resources (Levin, 2006).

The study employed a multi-stage sampling technique to select study participants. Firstly, two districts and then one sub-county per district, were all selected purosively. Subcounties of Paicho (Gulu district) and Koro (Omoro district) were selected owing to reports of a lucrative market and high turnover for pigs and pork in those administrative units (Ikwap et al., 2014).

Through simple random sampling, three parishes were selected from each sub-county. In Paicho sub-county, Pagik, Kal-umu and Kalali parishes were selected; while in Koro subcounty, Pageya, Labwoch and Guna parishes were selected. A complete list of all pig rearing households in the selected parishes was obtained from the respective sub-county headquaters and used to select the study sample of 239 respndents; the number which was determined using Yamane's formula (Yamane, 1967):

$n=\frac{N}{1+N e^{2}}, n=\frac{594}{1+\left(594 \times 0.05^{2}\right)}, n=239$ Equation 1

Where:

$\mathrm{N}=$ population, $\mathrm{n}=$ Sample size, $\mathrm{e}=$ Degree of confidence level at $95 \%$.

The 239 respondents were distributed between Paicho and Koro in portions of 143 and 96 pig farmers, respectively, based on pig farmers total populations per district.

Data collection. Primary data were collected using a pre-tested, semi-structured 
questionnaire. Pre-testing was done on $10 \mathrm{pig}$ farmers in Unyama sub-county, because the sub-county was near the study area; had similarly many pig farmers and yet it was not one of the sub-counties to be studied. After pretesting, questions that were well understood by respondents and generated consistent responses were maintained; while those that the researcher felt were important but earlier on omitted were included. Questions that seemed uncessary and/or redundant were removed. In some cases, re-ordering of questions was done to ensure logical sequency.

The questionnaires were administered in local dialect (Acholi), but recorded the responses in English. The data were collected using face-to-face interviews with pig farmers found in their homes. This allowed us to establish a rapport with the respondents, which enabled clarification of ambiguous answers and completion of all questions in questionnaires.

The questionnaire comprised of closed and Likert scale questions, in which respondents were requested to rate various items so as to ensure clarity of the questions to the respondents for easy answering. The questionnaire consisted of three parts. Part one captured routine socio-demographic information (Table1) and the type of labour used in the pig enterpriese; the variables included; use of family labour in pig enterprise ( $1=$ yes, $0=$ no), hire of labour for the pig enterprise $(1=$ yes, $0=$ no), number of casual labourers hired per year, number of permanent labourers hired per year.

Part two of the questionnaire gathered data on pig production, marketing and access to institutions and institutional services. The variables here included farming experience (years), current pig stock (number of pigs), distance to the nearest market, access to extension services $(1=$ yes, $0=$ no $)$ and access to credit $(1=$ yes, $0=$ no).

Part three captured farmer innovation behaviour data under its four dimensions. A total of 12 items were used to collect data on innovation behaviour; with each item rated on a five point Likert scale, where $0=$ not at all, $1=$ rarely, 2 = occasionally, 3 = frequently and $4=$ always as adapted with modifications from (Sullivan and Artino, 2013). The scale used had no neutral point so the measurement of intensity of innovation was progressive from the one end of a continuum to the other.

The items rated in the Likert scale for exploration included: (i) I am very curious about learning how to appropriately feed pigs; (ii) I like to learn new ways of housing pigs; and (iii) I like to take a chance of participating in training on new methods of pig disease and parasite control. For experimentation, the items included: (i) I like to experiment new practices of pig feed management; (ii) Among my peers, I am usually the first to try out new pig rearing practices; and (iii) I like to experiment new ways of erecting pig housing structures. Likewise, for the dimension of adaptation, the items included: (i) I alter new pig feeding practices to fit my situation; (ii) I adjust new pig housing practices to suit my situation; and (iii) I adjust new parasite and disease control practices to suit my farming situation. Lastly for modification of existing pig rearing practices, the items included: (i) I clearly understand how to modify existing pig housing practices; (ii) Modification of existing pig parasite and disease control practices is easy; and (iii) I use new knowledge to modify existing pig feeding practices on the farm.

Data analysis. The independent variables tested for prediction of family or hired labour utilisation by smallholder pig farmers included gender, age of household head (years), farming experience (years), household size, non-farm employment, distance to the nearest market $(\mathrm{Km})$ and education (years). For the categorical variables, the descriptive analysis performed were frequencies, percentages and chi-square tests; whereas continuous variables were analysed using means, standard deviations and t-tests. 
For studying the distributions of the four dimensions of innovation behaviour, indices were computed from Likert scale data from their respective items using the Equation 2:

$$
X_{i, k}=\sum_{j=1}^{j=n} a / b
$$

Where:

$X=$ index for the dimension of innovation behaviour; $i=i^{\text {th }}$ sampled pig producer; $k=k^{\text {th }}$ dimension of the innovation behaviour which includes exploration, experimentation, and adaptation of new pig rearing practices; and modification of the existing farm rearing practices; $j=$ number of items for a given dimension of innovation behaviour; $a=$ individual likertscore for a specific item by $i^{\text {th }}$ sampled farmer involved in pig production; and $b=$ total sum of ratings for the $k^{\text {th }}$ dimension of innovation behaviour.

To understand the level of exploration, experimentation, adaptation and modification in the study area, the farmers' innovation behaviour with respect to these dimensions was classified into five groups; namely none, low, medium, high and very high based on each respondent's exploration, experimentation, adaptation and modification index. No activity included farmers with a corresponding index of zero, 0.01-0.32 for low, 0.33-0.55 for medium, $0.56-0.78$ for high; while respondents with an index ranging between $0.79-1.00$ were considered to have very high innovation behaviour with regards to the dimension of interest. The described classification was adapted with modifications from Tirfe (2014) and Chopeva et al. (2015)

\section{RESULTS AND DISCUSSION}

\section{Characteritics of smallholder pig farmers} by type of labour used. Age, household size, education level, group membership, number of pigs and off-farm employment significantly $(\mathrm{P}<0.05)$ influenced pigfarmers use of different types of labour (Table 1).

Farmers who use both hired and family labour were significantly $(\mathrm{P}<0.05)$ younger than their counterparts who use only family labour. This finding conforms to an earlier study in Nigeria by Echebiri and Mbanasor

TABLE 1. Factors affecting the labour type used for smallholder pig production in northern Uganda

\begin{tabular}{lrrrr}
\hline Variable & $\begin{array}{c}\text { Pooled sample } \\
(\mathrm{n}=239)\end{array}$ & $\begin{array}{c}\text { Used only family } \\
\text { labour }(\mathrm{n}=192)\end{array}$ & $\begin{array}{c}\text { Used family and } \\
\text { hired labour } \\
(\mathrm{n}=47)\end{array}$ & P-value \\
\hline Age (years) & $37.73(13.36)$ & $38.70(13.50)$ & $33.77(12.13)$ & 0.023 \\
Household size & $7.02(3.31)$ & $6.73(3.40)$ & $6.15(2.80)$ & 0.045 \\
Education level (years in school) & $7.21(3.45)$ & $6.92(3.30)$ & $8.38(3.83)$ & 0.009 \\
Gender(1=Male)\% & 73.64 & 59.83 & 13.81 & 0.552 \\
Distance to the market (Km) & $1.12(0.42)$ & $1.14(0.46)$ & $1.02(0.15)$ & 0.084 \\
Extension service (1=Yes)\% & 35.98 & 29.29 & 6.69 & 0.757 \\
Access to credit (1=Yes)\% & 34.31 & 26.78 & 7.53 & 0.521 \\
Group membership (1=Yes)\% & 52.30 & 41.00 & 11.30 & 0.031 \\
Off-farm employment (1=Yes)\% & 57.74 & 12.97 & 44.77 & 0.003 \\
Pig rearing experience (years) & $4.251(4.31)$ & $3.89(3.22)$ & $4.34(4.53)$ & 0.527 \\
Pig stock (number of pigs) & $5.78(6.49)$ & $4.95(5.27)$ & $9.19(9.370)$ & 0.000 \\
\hline
\end{tabular}

*Note: Numbers in parentheses are standard deviations 
(2003), which reported that in Abia State, households who relied on only young people for provision of farm labour had less food production. This was because young farmers were more likely to be involved in other nonfarm activities than older farmers. This devotion of part of their time to other forms of income generating employment, other than farming explains the higher possibility of young farmers in the present study to hire labour for pig production. This result implies that young smallholder pig farmers are more likely to create more employment opportunities for their contemporaries, than aged farmers.

Household size was significant $(\mathrm{P}<0.05)$ in determining reliance of pig farmers on family labour. Farmers with large families tended to completely rely on family members for the labour needed; while those with small family sizes hired additional labour for use in pig production. This result is consistent with the findings of Nmadu and Akinola (2015), who found family size to be significant in determining farm labour supply and utilisation among crop farmers in Nigeria. This result suggests that smallholder farmers cherish large family sizes (wives and/or children) to guarantee this source of labour. Therefore, labour availability for pig production is higher in households with bigger family sizes than those with smaller family sizes. The present study, however, did not investigate whether households utilised the abundant labour supplied by big families effectively for pig production.

The effect of education on the use of family or hired labour was significant $(\mathrm{P}<0.01)$. Farmers who used both family and hired labour were significantly more educated than those who used only family labour. Farmers with higher education levels have been reported to often be involved in non-farm employment (Alassaf et al., 2011).This therefore, lowers their participation in farm operations and as a result such farmers tend to use hired labour for pig production. This result implies that education increases a farmer's ability and capacity to receive, comprehend and utilise information relevant to making farm labour decisions.

Membership to a group significantly influenced the type of labour used by pig farmers. Most farmers (41.00\%) who belonged to groups used only family labour; while others used both family and hired labour. Farmers in groups shared labour with fellow group members in what they called "aleya i poto" in Acholi, meaning "labour round". This practice of farmer peer support within groups increases labour availability, thus reducing the demand for and possibly cost of hired labour. Thus, belonging to a farmer group may increase labour supply, and reduce the cost of labour among smallholder pig farmers in northern Uganda.

Off-farm employment also significantly affected pig farmers' use of the two types of labour. Most (44.77\%) of the pig farmers with off farm employment used both family and hired labour, with only a few (12.97\%) of them using only family labour. This is because offfarm employment gives pig farmers additional income which may be useful in expanding their pig production enterprise and thus require hiring additional labour to supplement family labour for the enterprise.

Size of pig stock (number of pigs) statistically influenced farmer use of the different types of labour. Farmers who reared many pigs required more labour to take care of the various management activities. Thus, they were more likely to require hired labour compared to those with small stocks. Therefore, interventions seeking to commercialise smallholder pig production should support farmers' capacity to hire and manage additional labour to supplement family labour under certain circumstances.

There were no significant differences in the type of labour used by pig smallholder farmers based on gender, access to extension services, access to credit, distance to the market and pig rearing experience.

Distribution of the dimensions of innovation behaviour. Only modification of 
existing pig husbandry practices was normally distributed; whereas exploration, experimentation and adaptation were all skewed to the left. Results in Figure 1 indicate that all farmers exhibited some level of exploration, with most of them $(86.61 \%)$ having a very high rating in this dimension of innovation behaviour.

There were significant differences in the number of farmers who exhibited the different dimensions of innovation behaviour (Fig. 1). This means that the distribution of dimensions of innovation behaviour was neither mutually exclusive nor collectively exhaustive. Therefore, it was possible for a farmer to solely explore and not attempt the other dimensions. On the other hand, for a farmer to modify an existing pig rearing practice, he/ she does not need to first explore or experiment. This finding has profound implications for agricultural researchers, extension agents and policy makers. Mere availability of new technology/innovations does not necessarily lead to better adaptation and use by smallholder farmers (Lemessa $e t$ $a l ., 2018)$. Therefore scaling out of new agricultural technologies potentially requires address of other constraints that limit farmers' ambitions such as to limited access to credit and poor market linkages.

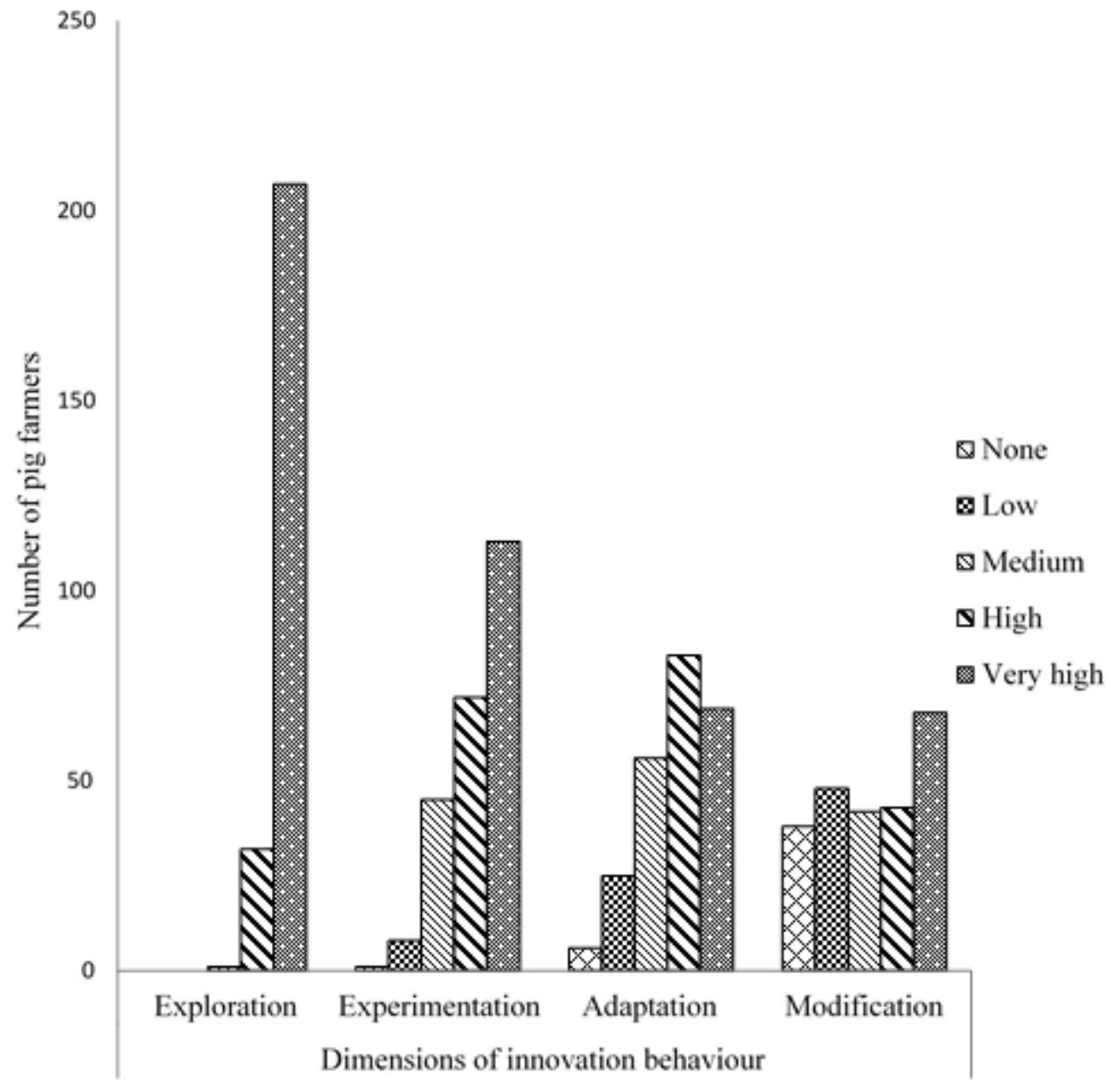

Figure 1. Levels of the dimensions of innovation behaviour among smallholder pig farmers in northern Uganda. 
In comparison with exploration, experimentation had considerably lower number of farmers (47.28\%), with very high level of experimentation index. Most farmers $(86.61 \%)$ were found to be very highly explorative because exploration is simply about observing or listening to what other people are doing/saying; without necessarily taking the initiative to either try out or modify the same. This result implies that it may be easier for smallholder pig farmers attend extension meetings and/or trainings than for them to implement what they have been exposed to (Moschitz et al., 2015). Accordingly, the development of smallholder agribusinesses among pig farmers through innovation requires innovators to actively involve farmers in technology development to facilitate coinnovation and co-learning; and to incentivise farmers to try out the new pig rearing practices.

Adaptation and modification dimensions depicted an increase in the number of farmers who exhibited inactivity for these two dimensions of innovation behaviour (Fig. 1). This is because these two dimensions of innovation behaviour require a considerable effort to alter what one observed or heard for either one's liking or adaptation to one's living and working conditions (Wettasinha et al., 2014). This result implies that effort is required to shift from one dimension of innovation behaviour to the next. The effort required for a farmer to innovate by successfully moving from exploration through experimentation and adaptation to modification, increases the labour demand for the pig production enterprise thus necessitating farmers with small family labour force to also hire additional labour. This implies that households with bigger family labour forces or those with hired labour will likely have higher innovation behaviour (Ndambiri et al., 2012). Therefore, interventions to commercialise smallholder pig farming through farmers' innovation behaviour should build the capacity of farmers to hire and manage additional labour.

\section{CONCLUSION}

This study has shown that young educated farmers with non-farm employment, a smaller household size, belonging to a farmer group and having many pigs are more likely to use hired labour than those with opposite characteristics. Therefore, interventions to boost pig production through the use of hired labour should consider the socio-economic differences among farmers which have been found to affect the labour constraints they face. There were significant differences in the number of farmers who exhibited the different dimensions of innovation behaviour. An extension of this study will be to investigate the factors which influence the dimensions innovation behaviour of pig farmers.

\section{ACKNOWLEDGEMENT}

The authors are grateful to the Mastercard Foundation and Regional Universities Forum for Capacity Building in Agriculture (RUFORUM) for funding research and publication cost through the Transforming African Agricultural Universities to meaningfully contribute to Africa's growth and development (TAGDev) Program.

\section{REFERENCES}

Alassaf, A., Majdalwai, M. and Nawash, O. 2011. Factors affecting farmer's decision to continue farm activity in marginal areas of Jordan. African Journal of Agricultural Research 6(12): 2755-2760. doi: 10.5897/ AJAR11.481.

Bedemo, A., Getnet, K. and Kassa, B. 2013. Determinants of household demand for and supply of farm labour in rural Ethiopia. Australian Journal of Labour Economics 16(3):351-367.

Bragdon, S. H. and Smith, C. 2015. Smallscale farmer innovation. Quaker United Nations Office. Geneva: Available at: https:/ /quno.org/resource/2015/12/small-scalefarmer-innovation. 
Chopeva, M. A., Nikolov, D. and Yovchevska, P. 2015. Farmers ' adaptation: What factors affecting agricultural innovations? Proceedings of the $147^{\text {th }}$ European Association of Agricultural Economists (EAAE) Seminar. Institute of Agricultural Economics, Sofia, Bulgaria. 1:1-13.

Ciaian, P., Falkowski, J. and Kancs, D. 2012. Access to credit, factor allocation and farm productivity: Evidence from the CEE transition economies. Agricultural Finance Review 72(1):22-47. doi: 10.1108/0002146 1211222114.

Èandek-Potokar, M., Nieto, R., Pugliese, C., Araujo, J. P., Charneca, R., Garcia Casco, J. M., Sanchez, G. E., Hernandez-Garcia, F. I., Izquierdo, M., Karolyi. D. and Kušec. G. 2017. Local pig breeds: Nutritional requirements, innovative practices and local feeding resources as challenges in projectTREASURE. Agriculturae Conspectus Scientificus 82(2):127-131.

Echebiri, R. N. and Mbanasor, J. A. 2003. Rural age distribution and farm labour supply in crop production systems in Abia State, Nigeria. Tropical and Subtropical Agroecosystems 2(1):129-136.

HarvestChoice. 2015. Pig population (head, 2005). International Food Policy Research Institute, Washington, DC and University of Minnesota, St. Paul, MN, USA. http:// harvestchoice.org/data/an05_pig. (Accessed: 5 August 2018).

Ikwap, K., Jacobson, M., Lundeheim, N., Owiny, D.O., Nasinyama, G. W., Fellstrom, C. and Erume, J. 2014. Characterization of pig production in Gulu and Soroti districts in northern and eastern Uganda. Livestock Research for Rural Development 26(4):62-79.

Lemessa, S.D., Watabaji, M.D. and Yismaw, M.A. 2018. Climate change adaptation strategies in response to food insecurity: The paradox of improved potato varieties adoption in eastern Ethiopia. Agriculture \& Food Security 1(1):1-11.
Levin, K.A. 2006. Study design III: Crosssectional studies. Evidence based dentistry 7(1):24-25. doi: 10.1038/sj.ebd.6400375.

Liao, Y. 2017. Innovation capacity and the implementation of eco-innovation: Toward a contingency perspective. Business Strategy and the Environment 19(63):132. doi: 10.1002/bse.1963.

Moschitz, H. Brunori, G., Roep, D. and Tisenkopfs, T. 2015. Learning and innovation networks for sustainable agriculture: Processes of co-evolution, joint reflection and facilitation. Journal of Agricultural Education and Extension 1(1):1-16.

Ndambiri, H. K., Ritho, C. N. and Mbogoh, S. G. 2012. An evaluation of farmers' perceptions and adaptation to the effect of climate change in Kenya. International Journal of Food and Agricultural Economics 1(1):75-96.

Ndyomugyenyi, E. K. and Kyasimire, J. 2015. Pig production in Kichwamba Sub-county, Rubirizi district, Uganda. Livestock Research for Rural Development 27(10): 1-14.

Nmadu, J.N. and Akinola, A. 2015. Farm labour supply and utilization for food crop production in Nigeria. Proceedings of the $2^{\text {nd }}$ International Conference on Education and Social Sciences (INTCESS15). Instanbul. 1:331-320.

Popadiuk, S. and Vidal, P. G. 2009. Measuring knowledge exploitation and exploration: An empirical application in a technological development center in Brazil. Proceedings of the XXXIII Encontro da ANPAD. Sao Paulo. 1:1-16.

Schiederig, T., Tietze, F. and Herstatt, C. 2011. What is green innovation? - A quantitative literature review. Proceedings of he XXII ISPIM Conference. Available at: http:// ssrn.com/abstract $=1846882$.

Sullivan, G.M. and Artino, A.R. 2013. Analyzing and interpreting data from LikertType scales. Journal of Graduate Medical 
Education 5(4):541-542. doi: 10.4300/ jgme-5-4-18.

Tambo, J.A. and Wünscher, T. 2014. More than adopters: The welfare impacts of farmer innovation in rural Ghana. Proceedings of the Agricultural \& Applied Economics Association's Annual Meeting 2014. Minneapolis.

Tatwangire, A. 2014. Uganda smallholder pigs value chain development: Situation analysis and trends. Nairobi, Kenya: International Livestock Research Institute (ILRI).

Tirfe, A.G. 2014. Smallholder farmers' innovation and its determinants: The case of Hirity Mekan Seed Producers' Cooperative, Tigray, Ethiopia. Developing Country Studies 4(21):104-115.

Wettasinha, C. Waters-Bayer, A., van Veldhuizen, L., Quiroga, G. and Swaans, K. 2014. Study on impacts of farmer-led research supported by civil society organizations. CGIAR Research Program on Aquatic Agricultural Systems. Penang, Malaysia. Working Paper: AAS- 2014-40.

Yamane, T. 1967. Statistics, an introductory analysis, $2^{\text {nd }}$ ed. New York: Harper and Row. 886pp. 